\title{
Contingent Proletarianization of Creative Labor: Deskilling in the Xianyou Classical Furniture Cluster
}

\author{
Kelly Wanjing Chen ${ }^{*} \&$ Jung Won Sonn ${ }^{* *}{ }^{\wedge} \times$ \\ * Department of Geography, University of Wisconsin, Madison, U.S. \\ ** Bartlett School of Planning, University College London, U.K. \\ $\wedge$ Corresponding author \\ $\times$ During this research, Jung Won Sonn had financial support from the Ministry of Education of the Republic of \\ Korea and the National Research Foundation of Korea, grant code NRF-2015S1A3A2047036.
}

\begin{abstract}
Champions of creative economy maintain that, unlike labor in manufacturing, labor in the creative industries is independent and innovative. They also claim that we are witnessing a linear transition from a manual to a creative labor-based economy. We argue against this idea of a sweeping, historical transition and instead posit that the labor process can easily switch from one to the other, depending on market conditions. We illustrate this theoretical point through an empirical study of the classic furniture industry cluster in Xianyou, China. Until around 2005, the region housed a typical low-skill, low-value added manufacturing cluster of small size. Since then it quickly transformed into a creative industry cluster where a small number of craftsmen performed both creative and manual work. However, the recent growth in the demand for classic furniture has enabled firms to mechanize the production process thereby creating new divisions of labor and turning the majority of the workforce into simple manual workers. At the same time, those who specialize in what remains creative in the production process are now liberated from manual work and enjoy greater creative freedom and higher status. Based on these findings, we conclude that, the transformation between creative and non-creative labor is reversible, industry-specific, and contingent upon the market rather than irreversible and economy-wide.
\end{abstract}

KEY WORDS: Labor process; Deskilling; Creative labor; Creative industry cluster; New economy; China; Chinese Classical furniture; Harry Braverman

\section{Introduction}

Tapping into the recent popularity of classical furniture in China, Xianyou, a county in the southern coastal Fujian province of China, has emerged as a major cluster of classical Chinese furniture production. It produces a variety of furniture products, many of which are custom made luxury goods. These delicate products convey the imagery of an old craftsman with a lifetime devotion to traditional craftsmanship working on one piece of furniture for 
many years. However, furniture manufactured in the Xianyou classical furniture cluster (XCFC) is largely the output of a mechanized labor process that is somewhat similar to Fordist mass production factories. Similar to other manufacturing industries, the majority of workers in local industry suffer through repetitive simple execution of the work orders that they are given.

This labor process seems to belie the shared perception among champions and critics of creative industries: that creative labor is qualitatively different from manufacturing labor, and thus the traditional mechanism of labor control through routinization of work does not apply. This stance assumes a binary distinction between creative work and manual work, as well as a teleological view toward the progression of capitalist economy, both of which do not always hold up against empirical evidence. In an attempt to reduce this discrepancy, through a longitudinal case study of XCFC, this paper demonstrates the back-and-forth transition between creative work and manual work is contingent upon various factors, especially market conditions.

The paper is organized as follows: The next section presents our analytical framework after a critical review of the literature on deskilling and creative work. Section 3 introduces our research strategy. Thereafter, Sections 4 and 5 report the main analysis sections that show the cluster's deskilling around 2010 and partial reskilling after 2014. Lastly, Section 6 concludes the paper by summarizing our main findings and discussing their wider implications.

\section{Creative work in contemporary literature}

Since the 1970s, global capitalism has experienced a qualitative shift marked by the aestheticization and semioticization of consumer culture in which the rapid invention of fads and fashions becomes the key strategy of accumulation (Harvey, 1991; Jameson, 1991). In advanced economies, where this trend began, the industrial landscape exhibited extensive reconfiguration involving the hollowing-out of traditional manufacturing centers and the rise of new growth cores that prosper off sectors ranging from computer gaming, software, and electronic publishing, to art, crafts, and fashion design (Zukin, 1995; Pratt, 1997; Scott 1997). Various terms, such as postmodern capitalism, cultural economy, and knowledge economy (Cooke, 2001; Harvey, 1991; Scott, 1996, among others), have been coined to label the phenomenon. Yet "creative" has become widely used inside and outside academic circles since the publication of Florida's (2002) The Rise of the Creative Class (e.g., Bontje and Musterd, 2009; Scott, 2010), a convention which we follow here.

One of the main themes in the debate on the creative economy centers on the industrial relation and labor process aspect. In contrast to the Fordist industries that aims to achieve economies of scale by standardizing products and cultivating mass consumption, creative industries based on flexible production system are assumed to, by nature, be impervious to the routinization of labor processes (Smith and Mckinlay, 2009). This perception leads to a romanticized depiction of creative labor in earlier work. Workers in creative industries are 
proposed to be the core of firms' competence. They are so empowered by irreplaceable skills that employers have to "spoil" them at the workplace with a high level of freedom. For instance, design firms often purposefully formulate a liberal workplace environment with computer games, gyms, and other recreational facilities to jump start the innovative engine of employees (McRobbie, 2002). Creative work is not only a process of exchanging labor power for money, it is also a process of self-realization and self-actualization (Merger, 1999; Markusen, 2006). This is reflected in creative workers' preference for contingent employment to more stable employment. Creative workers prefer the former because short-term contracts, project-based hiring, and part-time employment, allow them to develop multiple types of networks and hence acquire new skills and contacts (Grabher, 2002; 2004; Manning and Sydow, 2007).

This romanticization of creative labor has been the subject of criticism in recent years. Empirical evidence reveals that the irreplaceable skills of creative workers in actuality do not translate into bargaining power due to the chronic oversupply of labor. The cool appearance of creative industry, and increasing accessibility to education have created an expanding pool of artists, designers, programmers and others (Menger, 1999; Neff et al., 2005). To make things worse, technological advances have reduced the amount of labor needed to complete certain tasks. For example, in their study of media industries, Banks (2010), Caldwell (2008), and Christopherson (2008) found that the latest digital technology enables production and post-production work to be handled by a single individual today, as opposed to a production crew. Consequently, the majority of creative workers are faced with unemployment or underemployment (Ross, 2009). Confronted with cut-throat competition for jobs, many are forced to tailor their production toward the preference of employers, leaving little room for self-expression (Ursell, 2003; Christopherson, 2008).

Moreover, flexible employment, far from establishing a Bohemian lifestyle of freedom and individualism for creative labor, in most cases, only results in flexible exploitation (Brophy and De Peuter, 2007). Temporal staffing and freelancing, which have been the norms in creative industry, are shown to further disempower its practitioners (Perrons, 2007; Gill and Pratt, 2008). Sophisticated managerial techniques set in place to direct and extract workers' creative capacity (Blair, 2001; Lewis, 2004; Hesmondhalgh and Baker, 2008). Flexible employment spreads a widespread anxiety among creative workers, which leads them to take on multiple jobs at the same time and tolerate "slave wages" (Banks, 2007; Ross, 2009). With constant deadlines and long working hours, stress and pressure fill the everyday life of these individuals (Drotner, 2008), a condition that is well-described by the concept precarity (Butler, 2006). Other mechanisms to exploit creative labor such as the incorporation of traditional gender norms (Rantisi, 2014) and long-term internships (Banks and Milestone, 2010; Frenette, 2014), make exploitation less visible. In short, the much-celebrated creative class is, in reality, under the firm control of capitalist logic.

The critics cited above effectively dissolved its rosy image but even they do not challenge the myth that creative labor is impervious to deskilling. Such challenge is what we aim to do in this paper. In other words, we pose the question whether a reduction in the 
demand for skilled labor through the standardization and mechanization of the labor process, which Braverman (1974) observed in Fordist system of manufacturing, contribute to the proletarianization of creative labor.

The apparent absence of this question in the literature is partly due to two widely held assumptions about creative work. The first is a false dichotomy between the creative industry and manufacturing industry. While both types of industries are different in their ideal types, that difference does not legitimize the reduction of creative industry into purely creative works. Creative industries in the real world can be conceptually divided into various different types of work. A reasonable typology of work would consider a three-way distinction among design, craftsmanship, and simple manual work (Sennett, 2008). Design is the purely conceptual process of creating a new idea that does not yet have material form. The materialization of a design or the production process involves craftsmanship and simple manual work. Craftsmanship is the part of production process that takes a long time to master. The rest of the production process is simple manual work. We can consider design and craft as skilled work and simple manual work, non-skilled work. In real world creative industries, these three conceptually different tasks may or may not be performed by different workers. For example, in the traditional painting, all three are usually conducted by the same person. However, in conceptual art, a successful artist only thinks and craftsmen are hired to perform both craftsmanship and simple manual work. Even within the same industry in the same period of time, the allocation of these three types of works is contingent upon the context. For example, in a one-person boutique, the fashion designer would do all the cutting and sewing himself. A similar product, not necessarily of lower quality, can be produced in a global SAP brand where a designer only designs and production takes place in big factories with manual workers. Similarly, a furniture producer can be located in the spectrum between one artist/carpenter shops to IKEA without necessarily changing the quality of their products. Deskilling of the labor force can occur by identifying the simple manual work within the production process and assigning it to a worker who is not a designer or a craftsman. If there is enough demand for a certain creative sector, such the ratio of designers and craftsmen to the rest of workforce can be reduced.

The false dichotomy between creative work and manual work is strengthened by a common methodological bias embedded in existing work on creative labor. Researchers often rely heavily on information from a small number of privileged workers, such as designers, programmers, screenwriters, directors, and musicians (e.g., Rantisi, 2002; Roberts, 2007; Christopherson, 2008; Watson and Beaverstock, 2016). Thus, the rest of the workforce is often rendered invisible in the literature. Empirical evidence has shown that a considerable portion in this underrepresented pool of labor contributes to the production of ideas at work although they do not formally hold intellectual property rights. A good example is a make-up artist in the media industry (Christopherson and Storper, 1989; Banks 2010). Statistical research that might complement these qualitative studies is scarce because sector-based employment data seldom distinguish different jobs within the sector, especially in creative industry where small firms are dominant (Fleming et al., 2004; Markusen et al., 2008; 
Markusen, 2013). Considering the most creative part of the labor process only, one can easily conclude that creative labor is fundamentally different from traditional manufacturing labor.

In addition to the false dichotomy, the literature presupposes the teleological progress of history. The various versions of new economy discourse (Amin, 1994; Scott and Storper: 1992) often assume that the transformation from Fordism to post-Fordism occurred or at least started to occur in the 1970s. However, there is evidence that such transformation of capitalism was not that clear. Kiely (1998), for example, claims that the evidence offered by post-Fordism theories does not indicate a global transition within capitalism but rather a diversification in accumulation strategies. Harrison (1994) showed evidence that the Third Italy, which has been celebrated as the spatial manifestation of post-Fordism, was dominated by small firms and skilled workers only because the industry was at its infant stage. He reports that after twenty years of maturing, by the mid-1990s, either through the growth and merger of local firms or through multinational firms' takeover of local firms, big firms started to dominate this famous industrial cluster. We also know that the semiconductor industry, which was controlled during the 1980s by small firms in the Silicon Valley nicknamed Fair Children, is now dominated by MNCs such as Intel, Samsung, TSMC, Broadcom, and Qualcomm. Toyota's famous just-in-time production system, which was considered a sign of the triumph of Japanese-type post-Fordism, did not really diffuse to other countries or other sectors (Gertler, 1995). In general, there is ample evidence that challenges the idea of an irreversible transformation to a new stage of capitalism. This skepticism of the teleological view persuades us that even in creative industries perhaps old forms of exploitation, that is, standardization and routinization of labor processes are still at work.

We do, in fact, begin to see some empirical studies on creative industries that contradict the teleological view. Evidence of readjustments in operational strategies and subsequent reorganizations of the labor process in response to fast-changing markets and other external conditions abound in a large body of literature that examines the unfolding of this trend through meso- or micro-lenses (Pickles et al., 2016). For example, the recent growth of the artisanal furniture industry in South Africa occurred, in part, because the local firms lost the mass consumption market to imported products from China. In this case, a firm's move into the creative realm is an involuntary survival strategy and not a part of the global transformation into a creative economy (Murphy and Carmody, 2015).

The two aforementioned assumptions underlying existing literature on creative work underpin the popular perception that creative labor is immune to the conventional technique of deskilling. To tackle this problem, an approach that is sensitive to heterogeneity and multiplicity in labor processes is needed. First, the deconstruction of the binary assumption of the industry requires the acceptance of the fuzzy boundary between the two types of work. Both mass production and flexible specialization refer to ideally delineated industrial organizations with certain qualitative features. The actual labor process designed for most products exhibits a mixture of elements from both. In some craft-based creative industries, such as custom furniture manufacturing, fashion clothing, and jewelry making, this tendency is particularly evident (Scott, 2000; Rantisi, 2014). Therefore, in this paper, we recognize that 
similar products can be produced through various approaches for organizing work. Hence, there is no linear transition to a more evolved form of work. Rather, multiple strategies co-exist and a firm can employ one strategy today and switch to another a few years later.

To move beyond the second assumption, the teleological progress of economy, we focus on methodological improvement. First, investigation of the whole value chain is important because observing only certain segments of this long chain can bias the results. As mentioned earlier, part of the problem in the existing literature comes from the fact that only the most creative part of the value chain was paid particular attention. We will find a practical way to observe the whole production chain and labor process in each segment of the chain. Second, longitudinal data has to be collected to understand the temporal changes taking place over a certain period of time. Along with the cross-sectional data across firms, workers, industries, and clusters, we collected longitudinal data, enabling us to see what a snapshot case study would fail to show, that is, more complex changes of firm strategies occurring forward and backward between various types of labor processes or simultaneous use of them.

\section{Research Strategy}

\section{Case Selection}

We chose XCFC as the basis of our theoretical intervention. Located in the southern coastal Fujian province of China, Xianyou is historically a craft-rich county famous for its classical Chinese furniture. Local artisan's masterpieces were selected to furnish royal palaces since $10^{\text {th }}$ century AD (Chen and Huang 2012). However, it became a modern creative industry cluster only after the turn of the millennium. In the late 1980s, amidst China's transition into a market economy, Xianyou built upon its tradition to grow an export-oriented woodwork manufacturing industry. The bulk of regional exports consisted of mass produced wooden kitchenware and home décor, mainly supplying the nearby Taiwanese market (interview with Mr. Cai, a renowned craftsman from Xianyou, August $1^{\text {st }}$, 2014). In the mid-2000s, the region started to transform into a creative industry cluster as local entrepreneurs sensed the increasing popularity of classical Chinese furniture (interview with Mr. Tian, an officer at Xianyou Bureau of Arts and Crafts, December $28^{\text {th }}, 2011$ ). This fad was caused by a range of factors, such as increasing disposable incomes, rising nationalism, a booming Chinese housing market, and speculation on rosewood, which is the base material for traditional furniture (Huang and Sun 2013; Treanor 2015). XCFC quickly took advantage of this shift in preferences by combining modern machinery with traditional handicraft skills to produce rosewood furniture in the traditional aristocratic and royal styles of the Ming and Qing Dynasties of China. details (interview with $\mathrm{Mr}$. Xu, President of Xianyou Classical Chinese Furniture Industrial Association on December $12^{\text {th }} 2011$ ).

Despite similarities in the design of furniture, XCFC's production process is not the same as that of the olden days. The core woodcraft techniques remain the same compared to ancient times - carefully shaped and carved rosewood pieces are held together through sophisticated joints without glue or nails. However, the labor process has transformed 
significantly due to the incorporation of modern tools and machinery since the late 1980s (interview with Mr. He, expert on classical Chinese furniture, July 26 ${ }^{\text {th }}, 2012$ ). By 2014, the cluster comprised over 3,000 firms and 120,000 workers, generated a total annual output of 5 billion USD (Xianyou Bureau of Arts and Crafts, 2015). Such volume of output ranks XCFC as one of the major manufacturing bases for classical furniture within China, alongside Dongyang, Pinxiang, and Dayong (China National Furniture Association, 2015). Local production is composed of small batches of a wide variety of furniture products, whose designs update constantly in accordance with changing raw material supplies, market fads, and manufacturing techniques.

XCFC serves as an ideal case to contextualize our research question for two methodological reasons. First, the region hosts a relatively integrated labor process for manufacturing classical Chinese furniture, which is rare in today's highly globalized economy. Except for the sourcing of rosewood and common woodwork machinery, the entire production process is bounded to XCFC (interview with Mr. Xie, an experienced craftman on December 14th, 2011, and Mr. He, expert on classical Chinese furniture on July 26th 2012). The majority of finished products are then distributed within the domestic Chinese market, in addition to some minute flows into Japan, Taiwan, Singapore, and other developed countries in Asia that value the cultural connotations of such furniture (Treanor 2015). The spatial isolation of labor process in XCFC solves the methodological difficulties in studying skill changes. Without such a condition, it is difficult to draw the conclusion regarding general deskilling in the industry based on observed deskilling in one place. Deskilling in one place might not be representative of deskilling throughout the industry, but spatial relocation of skilled labor to other places.

Second, the unique qualities of XCFC within the context of China offers a rare opportunity to observe the effect of sudden market expansion. XCFC was formulated around mid-2000s, in succession to previous Fordist-style woodwork industry and grew quickly to be a national center of classical furniture within a decade. This short history also makes it easier to access longitudinal data. Those who experienced the major developments of the cluster are still operating in the cluster. It provides a unique opportunity to examine how dynamics within a creative industry affect the conditions of creative labor. It thus compensates for an empirical blind spot in existing literature, which lacks a temporal axis in addressing the class relation under new capitalism.

\section{Methodology}

We conducted five rounds of fieldwork in XCFC between 2011 and 2016. In these five rounds, we conducted 92 interviews, a questionnaire survey of 150 workers, and observations in numerous factories. The first round of fieldwork in December 2011 employed a combination of questionnaire survey and semi-structured interviews. The questionnaire survey was designed to understand the general labor process underlying classical furniture production. We received effective response from 150 workers across 12 firms of varying sizes, from which we gathered data on workers' job satisfaction, length of training period, and skill 
level as well as basic demographic data. We also conducted interviews of 34 firm owners, government officials, experienced workers, and other influential figures in the industry. In July 2012, a short follow-up round of fieldwork was conducted to further trace the changing condition of labor along the rapid expansion of local industry during which we conducted 10 more interviews with firm owners and shop floor employees.

The two initial rounds of fieldwork brought our attention to varying degrees of routinization that existed in steps along the labor process with clear features of creative work. This inspired us to conduct the next two rounds of fieldwork in February 2014 (9 interviews) and July-August 2014 (22 interviews). We selected firms with evident distinctions in labor process organization, and interviewed their workers who perform different roles in production activities, as well as managers and firm owners. The interview was designed to understand the heterogeneity of labor process that sustained Xianyou's creative industry and its deskilling impact on the local labor force. Information collected through interview was complemented by multiple visits to factories where we observed production practices in detail.

In January 2015, we conducted the last round of fieldwork to examine the fluctuations that XCFC was undergoing due to the introduction of a new craft techniques and changing market fads. 17 interviews were conducted with owners and workers from firms that was highly influenced by such fluctuation.

In addition to these primary data, we also use secondary data from governmental reports and mass media. Although these materials tend to emphasize positive aspects, they do contain valuable information like key statistics and interviews of influential figures.

\section{Deskilling of Creative Labor in XCFC}

Through interviews with workers, and multiple factory tours, we confirmed that the manufacturing of classical Chinese furniture involves five major steps. First, a design needs to be consolidated to define the appearance and inner structure of the furniture. Rosewood raw materials would then be sliced and shaped into components. Following this step is the crucial process of wood carving, which involves decorating components with delicate patterns that could significantly enhance the aesthetic and symbolic value of the product. Carved components would then undergo the last two steps, assembling and polishing, before becoming an end product ready for the market. Amongst the entire labor process, furniture design and manual wood carving stand out as the most skilled work.

In the three-way typology that we explained in the previous section, furniture design is obviously a type of design work. Manual carving in XCFC is mainly craftsmanship but often has substantial level of design in it. As many of the decorative details applied in classical Chinese furniture cannot be fully defined through design blueprint, craftsmen practicing manual carving are in actuality practicing brainwork and craft work at the same time. This is particularly true in the fashioning of sophisticated decorative patterns like human figures and animals, wherein the facial expression and texture of hairs/feathers are all left for the carvers 
to fill (See Photo 1). Laborers involved in performing these creative parts of the labor process are the most skilled. According to questionnaire survey result (2011), furniture designers typically consist of college educated industrial designers and experienced craftsmen with at least five years' experience in local industry. Similar situation holds among manual carvers whose average training time is around three years. Laborers involved in the rest of the production process are significantly less skilled, whose training period ranges from several days to several months.

While the general five-step labor process is common among classical furniture firms in Xianyou, exactly how those five steps were done differs firm by firm. As a part of the fast-growing market, firms noticed that there were different types of consumers who sought various types of products, and thus, they began to adjust their operational strategies to focus on clearly targeted segments. Such changes in business strategy have resulted in increased heterogeneity in the labor process across local industry firms.

In order to understand the variety of the labor process systematically, we begin by categorizing the firms. In Table 1, the horizontal axis represents the degree of mechanization, while the vertical axis represents vertical and horizontal integration. This two-dimensional categorization results in four ideal types of end product producers, which we call flexible mass producers, modernized traditionalists, adapters, and traditional workshops, respectively.

A flexible mass producer (FMP) is a vertically integrated, extremely mechanized firm. We call these firms FMP because they combine the principles of mass production and flexible small batch production. We identified several firms that belong to this category during our fieldwork, for instance, Liantianhong (连天红) and Shanzhonggudian (山中古典).

A modernized traditionalist (MT) is vertically integrated like an FMP, but is substantially less mechanized. MTs are the most prestigious among the four types and produce the most expensive products. One such firm, Sanfu (三福), sold a throne for 1 million USD at an auction on April 7, 2014. That piece was so highly valued mainly because of the craftsmanship that machines cannot mimic.

In addition to these two types of medium and large factories, there are numerous small enterprises. We categorize these small firms into two types, namely traditional workshops (TW) and adapters. TWs refer specifically to small firms with limited mechanization. Usually run by experienced craftsmen. This type of firm maintains a high rate of manual labor in its labor process in some cases comparable to that of a modernized traditionalist. A common operational strategy is to invest in maintaining a highly skilled workforce within the firm's own factory while outsourcing processes involving heavy machinery, like computerized wood carving, to mechanical processors that will be explained later.

Adapters are highly mechanized and produce goods for lower-end customers. In order to reduce the cost of production, such firms often choose to compromise on the quality of their products. Most of TWs and adapters were established in late 2000s when local industry was experiencing rapid expansion. They are often financed by small local investors (interview, December 30th, 2013). Because of limited access to capital, they depend on a flexible inter-firm production network, both vertically and horizontally (Zhu, Chen and Dai, 2016). In 
addition to flexible inter-firm relations, these firms have flexible labor relations which blurs the boundary between TWs and adapters. Quickly responding to market changes, an adapter can and does quickly transform itself into a TW by hiring workers with higher skills and readjusting the labor process and vice versa.

There exists a fifth type of firm within XCFC - mechanical processor. These firms specialize in mechanized steps in the manufacturing process especially CNC wood carving. Since they are not end product producers, mechanical processors are generally integrated into local production systems through outsourcing from TW's and adapters.

Below, we will explain how each of these types contribute to deskilling in XCFC.

Table 1. Typology of Firms in XCFC

\begin{tabular}{|c|c|c|c|c|c|c|}
\hline & \multicolumn{3}{|c|}{ Mechanization } \\
\hline & & & & & & Low \\
\hline \multirow{2}{*}{ 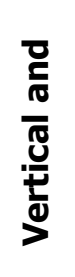 } & \multirow{2}{*}{\multicolumn{2}{|c|}{ 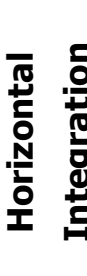 }} & High & $\begin{array}{r}\text { Flexible ma } \\
\text { (e.g., Liantianh }\end{array}$ & $\begin{array}{l}\text { ducer (FMP) } \\
\text { hanzhonggudian) }\end{array}$ & $\begin{array}{c}\text { Modernized traditionalist (MT) } \\
\text { (e.g., Gongpinxuan, Sanfu) }\end{array}$ \\
\hline & & & Low & $\begin{array}{l}\text { Mechanical } \\
\text { Processor }\end{array}$ & $\begin{array}{c}\text { Adapter } \\
\text { (e.g., Deyitang, } \\
\text { Hongtuge) }\end{array}$ & $\begin{array}{l}\text { Traditional Workshop (TW) } \\
\text { (e.g., Yanshihengye, Yubaofu) }\end{array}$ \\
\hline
\end{tabular}

Source: Authors' compilation based on original data

\section{Flexible mass producers and extreme polarization of skills}

The labor process in an FMP is quite similar to that in a Fordism factory, although the composition of the output is different. Employing a relatively stable on-site workforce with usually hundreds of employees this type of firm divides the labor process into highly detailed tasks, which it assigns to individual workers. For example, the manufacturing of a bench could be divided into nearly 100 separate steps. Workers are strictly limited to performing their assigned tasks, and are not allowed to move around the shop floor. They are required to repeat the same or similar actions, most of which involve pure execution such as slicing planks into wooden blocks of a certain size or punching holes in the ends of certain components (questionnaire survey, December 2011).

This is not to say FMPs are similar to typical mass producers in every aspect. FMPs produce hundreds of different products in small lots. Even in the most popular designs is not applied to more than one hundred pieces. This variety of products, however, facilitates, rather than hinders, the routinization of labor process. An FMP can standardize parts across various final products by concentrating the conception task into a small design team that comprises furniture designers with a degree in design, the best local artisans, and traditional Chinese artists. The team produces a strict blueprint that maximizes the use of common parts for a variety of final products. The rest of the workforce, following a strict work order, spends their time cutting hundreds of the same wooden blocks that will eventually be assembled into a variety of products (Two Interviews with Mr. Huang, shop floor manager of Firm L on December $28^{\text {th }}, 2012$ and August $3^{\text {rd }}, 2014$ ). 
In FMPs, wood carving, the important step that sees the concentration of creative work besides furniture design, is mainly conducted through CNC wood routers. Instead of allowing months for skilled craftsmen to work on one piece of furniture, a wood router can finish the same task, albeit with much less delicacy, within a few hours. In some cases, semi-finished furniture components fresh off wood routers are improved with a touch from craftsmen. Such arrangement has two effects on manual carvers. First, this obviously reduces the number of carvers needed in the labor process. Secondly, the retained carvers do not need to spend time on simple tasks and may concentrate on the most skilled part of furniture production, thereby improving their skills even further. Their prestige and skills can be inferred through their income level. Manual carvers are the highest paid group among workers in FMP. In 2014, their wages were between 40 and 50 USD per eight-hour workday, which is a substantial salary in a county where the average daily income is around 10 USD. (Interview with senior workers of Firm L, August 4th, 2014; Fujian Statistic Bureau, 2016)

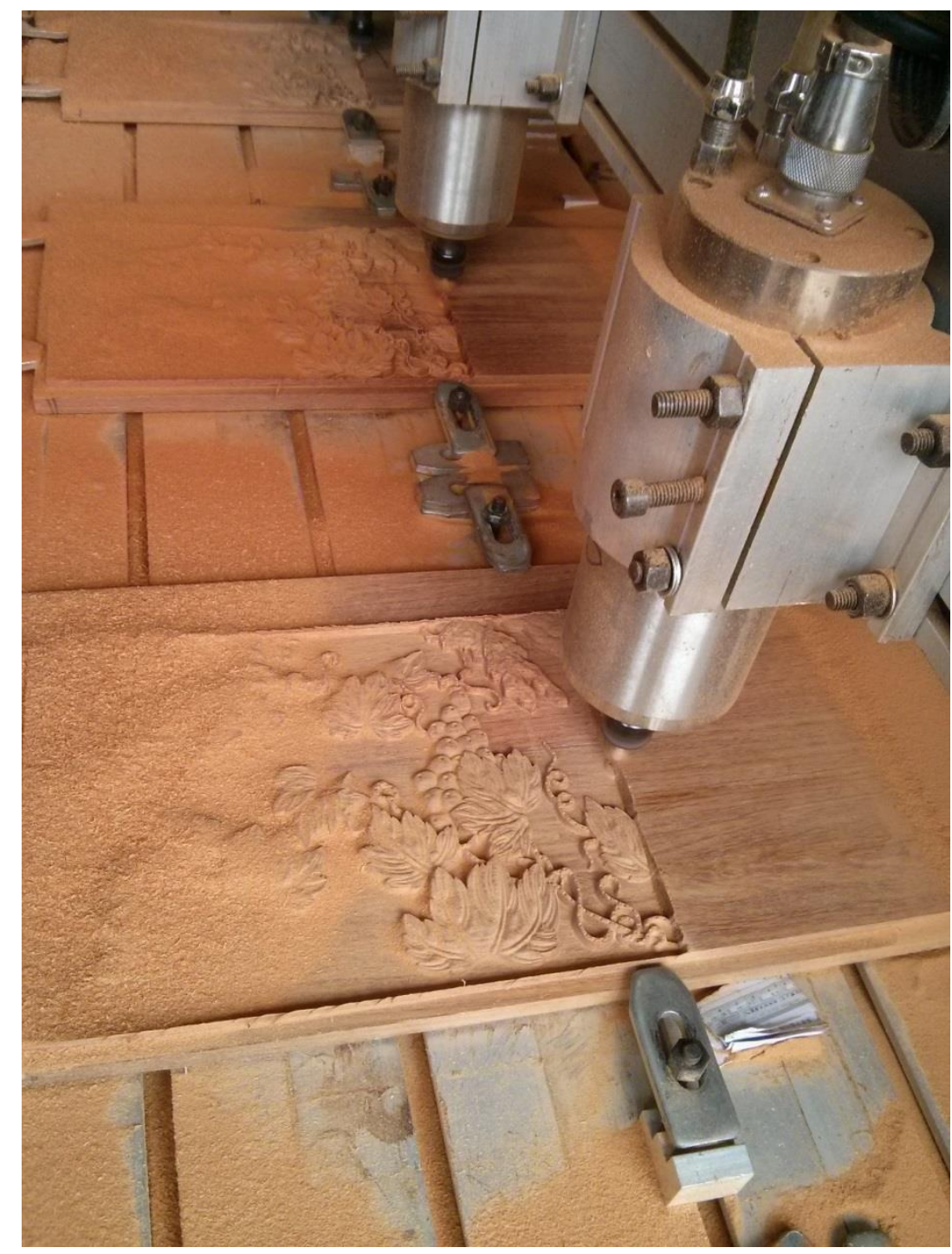

$<$ Figure 1 > CNC Wood Router 
Mechanized carving tasks require support from two groups of workers, namely machine operators and programmers (questionnaire survey, 2011). The first group of workers is noticeably composed entirely of young men. That is mainly because employers expect machine operators to be, according to a shop floor manager, "healthy enough to endure longer working hours ... as obviously machines keep running when other workers get off work." Their work is extremely simple, for example, "checking if the patterns carved by the routers turn out to be the way they are supposed to," "reporting any malfunctions of routers," and "replacing the steel needles on routers after they wear out." These trivial tasks can be conducted by any individual without any previous knowledge of the industry after minimal training, often lasting for no more than a few hours. In 2014, for a 12- to 15-hour workday, machine operators were paid less than 25 USD, on average (Interview with workers from Firm L, August $4^{\text {th }}, 2014$; Interview with workers from Firm S, December $27^{\text {th }}, 2014$ ).

A proponent of reskilling would predict that the deskilling in production should be accompanied by an increase in skilled workers elsewhere, that is, CNC wood router programmers in this case. However, wood router programming is not a highly skilled job. Carving can be programmed simply by digitizing a design blueprint with software such as CorelDraw or AutoCAD, followed by minor modifications of the software's template parameters. This skill level can be acquired easily with a short training program that CNC wood router suppliers in the county offer at no cost. According to an instructor of one of these classes, even those without a background in arts and crafts can acquire sufficient level of programming skills by taking a course of less than two months (Interview, August $1^{\text {st }}, 2014$ ). This is more or less consistent with the findings of our questionnaire survey (2011), where all wood router programmer surveyed reported that they had less than half a year of training.

The dynamics within FMPs show that creative work can be divided, routinized, and mechanized, if needed. By reorganizing the labor process, production that previously required highly skilled, well-rounded craftsmen can now be done by a highly polarized on-site workforce, the majority of which are low skilled or semi-skilled.

\section{Modernized traditionalist and intergenerational deskilling}

Some firms with enough financial resources chose to target the highest-end consumers like professional collectors, whose primary concern lies in the quality of the product, in terms of both its artistic value and the rarity of the raw material. Such firms adopt a different strategy from that of FMPs in organizing their production. The labor process in these firms is standardized and mechanized to a limited degree. One executive manager from Firm B, a MT firm we visited in July $28^{\text {th }}$, 2014, quantified the difference by saying that only 20 percent of work in this type of firm is conducted by machines, compared with 80 percent in FMPs. This estimation was agreed upon by several interviewees from other FMPs when we attempted to crosscheck.

Born to prestigious craft families, the owners of renovated traditional factories possess a much more comprehensive understanding of and respect for craftsmanship. In these factories, we noticed that the labor process is predominantly manual involving only simple 
tools. A manager of Firm G, a typical MT type of firm, confirmed in an interview with the authors on August 2, 2014 that mechanization is found mainly in the initial stages of the production process (e.g., slicing logs into components with wood slicers). In their two three-story factory buildings, we came across several wood routers. The most skill-intensive part of production, woodcarving, is performed manually by highly skilled craftsmen so that the quality of the products can be ensured. In our fieldwork in 2015, we observed a shop floor filled with almost 100 skilled craftsmen, each occupying approximately $1 \mathrm{~m}^{2}$ of space, and applying carving techniques with a chisel and knife to rectangular wooden slates. According to the manager, each of the slates would take a worker a year to complete.

In an MT, there is certain degree of separation between designers and craftsmen. This separation does not, however, lead to the downgrading of craftsmen into pure manual executors. Firm G, for example, has a six-member team consisting of two skilled craftsmen, one Chinese classical artist with degree in art, one interior designer, and two programmers. The design team takes several months to discuss and create a new design. That design is, however, a conceptual design with high level of flexibility built in it, not a specific blueprint that represents strict work orders. The implication of this flexibility is that opportunities for creativity is distributed widely along the labor process, rather than being concentrated in the design team (Interview with manager of Firm G, August $2^{\text {nd }}, 2014$ ). In firm G, we discovered blueprints that simply contained the outline of an eagle. When put into production, manual carvers must use their own creativity and skills to fill in this outline with textures that resembled feathers in their own way. Each individual craftsman autonomously controls a product's entire carving process to avoid possible inconsistencies in the final product. Some of these craftsmen earn a daily wage of 200 USD, 20 times the county's average wage.

Overall, the labor processes in these factories resembles those of traditional craftsmen's workshops. Unfortunately, this resemblance does not contribute to the maintenance and reproduction of the cluster's skill levels, as champions of the creative economy would hope and predict.

First, novices in the cluster do not have the opportunity to learn from these firms' skilled craftsmen. Because the easiest jobs are mechanized, there are no opportunities for those who want to use simple jobs as an opportunity to gain more skills (questionnaire survey, 2011). Second, even the small number of unskilled workers hired in these factories do not have sufficient opportunities to observe and learn what skilled workers do because they are required to stay in their allotted space. Unskilled workers "don't even talk to skilled craftsmen much" according to an unskilled worker in Firm G (Interview on August $2^{\text {nd }}, 2014$ ), which was confirmed by an interviewee in Firm S (Interview on January $2^{\text {nd }}, 2015$ ).

Finally, concerns over imitation by competitors leads firms to forbid their employees from exchanging industry-related ideas and techniques outside of the factory (Interview with owner of Firm B, July 28th, 2014). Champions of creative industries describe creative workers as having loyalty to the peer community rather than to the employers. As a result, they freely exchange ideas across firms, which makes a cluster into a space that is abundant in knowledge spillovers. This is not the case here, at least not among this clusters' best 
craftsmen who have secure employment in MTs. The less skilled workers in MTs are not subjected to similar strict rules of knowledge sharing and display higher job mobility. However, their relatively low engagement with more skilled staff from their firm due to division of labor and hierarchy between the employees renders it difficult to access core knowledge on furniture manufacturing (interviews with workers, July- August 2014). Hence their role in facilitating knowledge spillovers is minimal. The scarcity of knowledge spillovers translates into a scarcity of opportunities to become craftsmen for younger generations of semi-skilled workers, a situation that many workers in this skill range repeatedly told us over the course of various factories tours that took place between 2012 and 2015.

Unlike the FMPs, MTs offer opportunities for the best craftsmen of the cluster to put their best on product and to improve themselves. However, by failing to offer learning opportunities to the new generation of workers, in the long run, MTs are contributing to a gradual deskilling of the workforce in the cluster, which we call "intergenerational deskilling."

Adapters, mechanical processors, and absence of skills.

While the two types of firms previously discussed are more visible, owing to their size and prestige, the most common are small firms in the low value-added niche (Zhu, Chen and Dai, 2016). Between the two types of these small firms, mechanical processors perform most simple process with the machine as we explained earlier so there is no need for further explanation why they do not contribute to reproduction of skills.

The adapters keep manual tasks on-site while outsourcing the most mechanized tasks to mechanical processors in the region. These firms contribute to the general deskilling of the cluster by failing to employ skilled workers in design and in crafting.

On the design side adapters produce a relatively narrow range of products. Because they cater to a consumer group that cares more about the genuineness of the raw material than about the design, adapters expend minimal effort on design. Second, as the owner of Firm $\mathrm{H}$ shared with us, once a particular set of designs is found to sell well, then adapters will continue to produce these designs up to the maximum of their production capacity so long as they sell. Firm $\mathrm{H}$ has been producing the same living room sets since 2012 and has sold hundreds of them for two years. The firm was only developing new products when we visited them (2014) because the investment boom in rosewood was dwindling. (Interview with workers in Firm H, July $23^{\text {rd }}$, 2014). Even in the case of these small number of designs, these firms' "designers" do not really design. They mostly work on digitizing high-resolution photos of furniture that is popular in the market or that is demanded by consumers, which, as discussed earlier, does not require special skills.

On the craftsmanship side, the continued production of the same products and repeated tasks reduces workers' opportunities to gain experience in creating diverse product types (Interview with workers in Firm H, July $23^{\text {rd }}$, 2014). But more importantly, to bring down the price, adapters are willing to compromise on quality. It is common to remove or reduce small 
tasks in production that have less discernible impacts on the final output. For instance, components are assembled with glue and nails instead of mortise and tenon structure, even if the latter ensures the durability of furniture and the integrity of the raw material (interviews with workers and observation in Firm H and Firm D in July 2014).

Adapters certainly contribute to deskilling in the cluster. Adapters hire a large portion of newcomers to the industry but do not provide opportunities for learning-by-doing or learning-by-observing. In fact, the simplification of the tasks performed by most adapters also hinder future learning. Because workers do not have the opportunity to learn proper techniques, even after leaving an adapter, they end up being employed by another adapter. For example, while gluing to join together a mortise and tenon structure is regarded as a disgrace to craftsmanship, that is what workers in adapter firms learn.

Furthermore, learning about discipline is hindered. To be a skilled craftsman, a worker should undergo harsh processes of learning to cultivate the necessary patience for tedious tasks and paying attention to details. If an apprentice gets accustomed to quick and easy methods at the beginning of his career, he cannot simply decide to work differently later on in his career. Throughout our fieldwork, we often encountered semi-skilled workers who, while longing to improve their woodcrafts skills to leverage for higher wage and social status, bitterly admitted that their "old habits" in production are hard to change. One worker from Firm D further explained how his hand dexterity o and strength in his arm muscles had been shaped over the years by the repeated process of bending wood batten for Ming-style armchair in a quick and cheap way. Consequently, the curves that he created were fixed and extremely difficult to improve on aesthetically (Interview with Firm D worker, July 26, 2014).

Thus, once an individual learns within the adapter's production method, it is extremely difficult to advance his career toward a more creative job. A worker from Jiangxi province informed us that he has worked for seven different firms since 2013. However, his work has been "more or less the same everywhere," because "firms with a different way of production would not hire me." According to him, most individuals who start their career in adapter firms are likely to continue their career in other adapter firms.

We expected workers to detect at least some opportunities for learning from each other within the firm. However, performance-based payment forces workers to focus on immediate output, rather than learning. Workers are also charged for wasted material, which prevents them from practicing unfamiliar techniques. As the owner of Firm $\mathrm{H}$, another adapter firm we encountered in our fieldwork said, "the profit margin in our factory is really, really low. If you break, let's say a chair's arm during production, then there is no profit."

In that sense, the main problem in terms skills in both adapters and mechanical processors is not the polarization between skilled work and simple manual work. Rather, it is the near absence of design and craftsmanship.

\section{Traditional workshops and the externalization of deskilling}

Finally, there are small firms in the region that tailor their production toward high-end 
customers, whose concern over the quality of products outweighs their consideration of prices. Though similar in size to adapters, traditional workshops have a different labor process.

These firms only externalize the tasks that are highly mechanized and that do not have much influence over the quality of the final product, such as cutting planks into components using a sawmill, and desiccating rosewood logs in an industrial oven. However, wood carving, as an essential step that determines the delicacy of the final product is performed internally by highly-skilled craftsmen.

TWs are often established by craftsmen, and employ only a handful of highly skilled workers. As several TW owners and employees confirm, workers in TW receive an hourly wage rather than performance-based wage. This wage system allows the craftsmen spend time putting his best skills into the product. That system also cultivates the culture of knowledge exchange and learning. Workers often engage in long and serious discussions with one another usually about product design (Authors' observation in Firm Y and Firm S in July 2014 and January 2015). For example, in our visits to Firm S in July 2014, we observed two workers discussing the potential for a piece of timber with an uncommon shape. During the conversation, they would draw sketches on the floor or directly marked the timber up with chalk. One felt the timber could be turned into a statue of Buddha, while the other insisted on a peacock or another bird. This certainly seem quite close to the scene that is probably one would see in furniture workshop one two the champions of creative industry would expect.

However, when it comes to training opportunities for apprentices TWs would disappoint the champions of creative industry. Instead of hiring apprentices for simple jobs, and let them learn higher skills on the job, TWs outsource simple jobs to mechanical processors that we explained in the previous subsection. During our tours of several TWs, we met firm owners who enthusiastically explained their exciting plans for some newly acquired, high grade raw materials. In addition to their plans for design and marketing, they would always say things like "I'm going to have it sliced in my friend's firm," or "my cousin's factory can take care of painting and waxing afterward."

The TWs that offer a creative environment for the most skilled workers are heavily dependent on unskilled labor in other firms within the cluster. In that sense, the entire value chain actually resembles an MT except that the skilled jobs and unskilled jobs are done in legally, financially and spatially separate establishments. This outsourcing of unskilled labor by TWs reduces learning opportunities even more than MTs do. That is because opportunities for low-skilled workers in MTs do not exist at all in TWs because unskilled jobs are performed in a different factory. Even if deskilling does not happen in TWs, TWs are only externalizing deskilling.

It should be also noted here that the flexible organization and employment that are often celebrated as the ideal environment for creativity actually create the conditions for externalization of deskilling. That is related to the fact that a TW can transform itself into an adapter by hiring the relevant type of workforce, which we mentioned in section 5 . When workers' tenures are short, firm owners have little incentive to train their workers. Thus, the 
firms hire skilled workers only and the cost of training is passed on to the workers that very few workers can actually afford.

\section{Exogenous innovation as an opportunity for reskilling?}

The Arrival of an innovation from outside

During our longitudinal observation in XCFC, we observed the arrival of innovation from outside. Around 2014, local firms competed to acquire a new carving technique, called feather carving or "Si Ling Tan Diao" (丝领憻雕) in Chinese. Developed by a Shenzhen craftsman, Xiangwen Shao around 2010, this technique is a bas-relief technique that displays the delicate texture of objects with the arrangement of fine lines. In 2011, his brush pot was officially included in the he Palace Museum's collection, an extremely rare recognition that a piece deserves a spot among the ancient masterpieces in the Museum. (Tian, 2011). This excited professional collectors, and soon influenced wider consumers. The growing demand was mainly for feather carving products but the demand for high quality craftsmanship increased generally. Factories in XCFC obviously tried to take advantage of this demand. (Xinhua News, 2015).

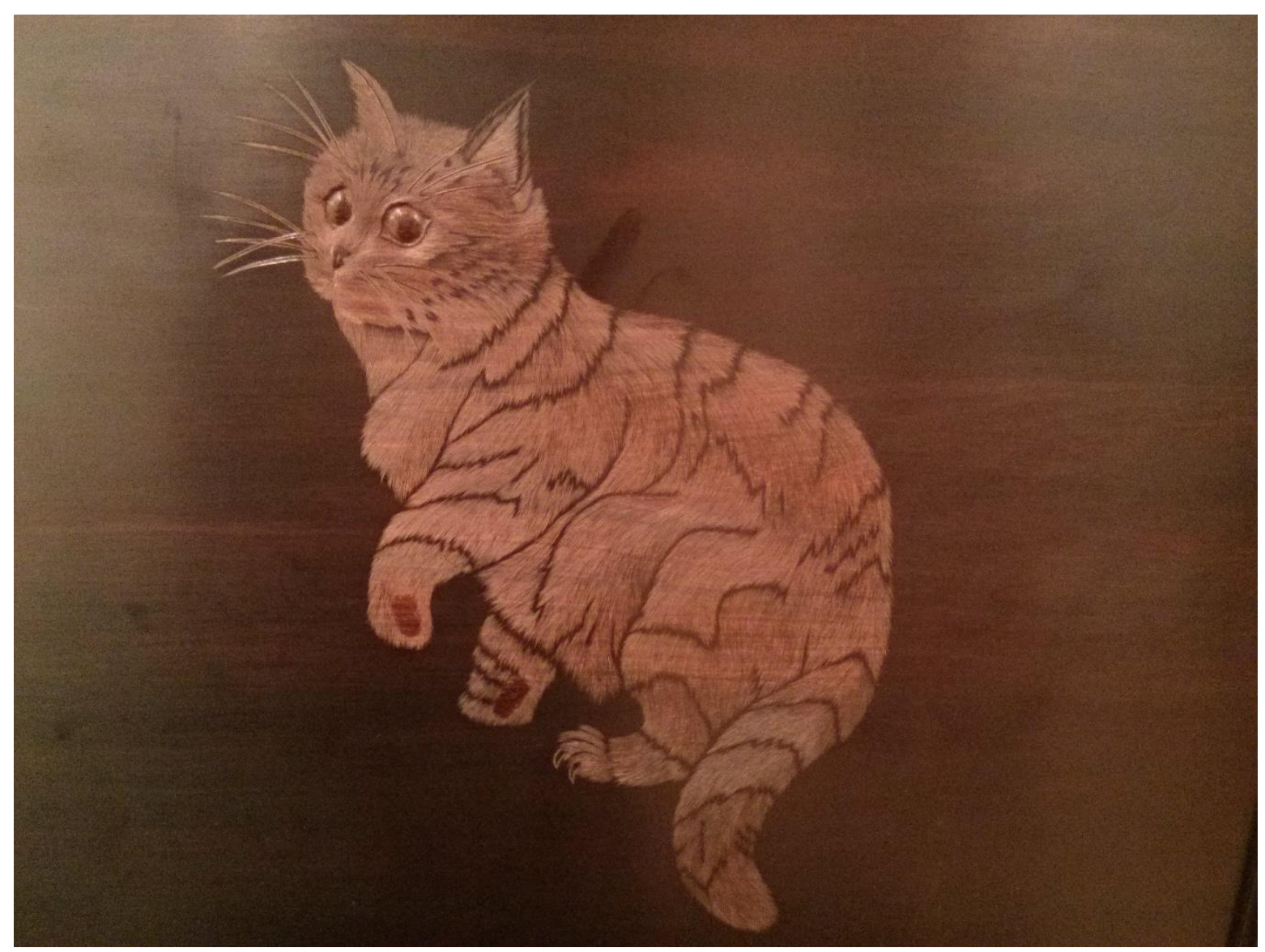

$<$ Figure 2> A Relief of Cat based on Si Ling Tan Diao Technique

The incorporation of feather carving, as well as subsequent market fads, brought a 
renewed emphasis on design and craftsmanship in the XCFC around 2014 (interview with manager of Firm G, August 2, 2014). Firms became less reliant on CNC wood routers in production. At the same time, wood carving steps were more fully integrated. The traditional method, that is, one person taking charge of an entire carving process, became more common because two craftsmen's feather carving techniques is rarely identical, and thus, creates inconsistency in the product (Interview with senior craftsmen from Firm Y, January $3^{\text {rd }}, 2015$ ). This reskilling is most noticeable among small firms, whose flexible organization gives them an edge in responding to the market shift. In the winter of 2015, we revisited a firm that we had previously categorized as an adaptor to find that its shop floor was now filled with 20 workers who were all capable of feather carving. Several CNC wood routers were lying unused in a corner of the factory. Skilled craftsmen are the biggest winners in this wave of the feather carving craze. After having learned this new carving technique, their daily wage stood to increase to around 100 USD per day. However, the majority of low-skilled and semi-skilled labor failed to benefit from the trend because it is almost impossible for them to master such a difficult technique before it goes out of fashion even if there are opportunities for learning.

\section{The emergence of formal training program}

When feather carving skills came into demand, some TW's transform themselves into formal education institutions, a trend that we observed during the fieldwork in January 2015. However, despite the potential wage of 100 USD per day, the number of trainees did not grow quickly. The reason is understandable: for a low-skilled worker it could take several years before he masters the technique. The process requires extreme hard work and its outcome is not fully guaranteed. There is a fee of 400 USD before a worker can perform any tasks in these factories. Zheng, a local young man who builds mortise and tenon structural components using a machine, was once enrolled in a training program at the beginning of 2014 but soon quit. His remarks reflect the general attitude of the low-skilled labor.

I started out ambitiously, aiming at a high wage. But I quickly realized that if I only spent several months in training, I can only reach the lowest level of woodcarving skills, getting \$30 a day. I would have to spend several years in training, and the outcome could still not be guaranteed because, sometimes talent matters more than efforts..... It is much easier for me to work with the machine.

We did encounter some workers who completed training and acquired certain feather carving techniques, and then subsequently earned over 100 USD per day. In Firm Y, the small firm specializing in producing feather carving products, all of their 20 craftsmen went through a similar short-term training program, and experienced a $20 \%$ to $30 \%$ increase in wages. However, they were few in number and, more importantly, had already had certain level of skills before entering the program. 


\section{Conclusion}

Creative workers who face low wage and cut-throat competition against their colleagues would dream of a situation where demand suddenly soars and all their fellow creative workers may enjoy self-actualization through creation without worrying about meeting their necessities. In the case of XCFC, the demand did soar, but it did not offer scope for self-actualization. Instead, increased demand helped employers "rationalize" the production process to benefit only a small number of designers and craftsmen while deskilling the rest of the workforce.

Observing such a phenomenon persuaded us that orthodox Marxist's theory of deskilling is extremely useful for understanding the proletarianization of creative labor. As perception can be separated from execution can be separated and the latter can be routinized in manufacturing, which Braverman (1974) reported in detail, creative work can be divided, mechanized, and computerized. Using various techniques, backed by managerial science and technological advancement, labor processes can be reorganized to reduce and concentrate creative tasks into a few hands while routinizing the other tasks. Consequently, a polarized workforce manned by the majority of unskilled or semi-skilled labor struggles to maintain its livelihood through long hours of work and meager wages.

However, the way in which deskilling unfolds was not as simple as Braverman described. Various types of firms employ different ways of deskilling involving various ratios of deskilled to skilled workers. The common image of a mass producer is that it sacrifices the quality of the product and increases the share of simple manual work within the production process. Such practices were certainly found in XCFC, partially in FMP's but mainly in adapters. However, in MT's and TW's, mass production was achieved without sacrificing the quality of the product. As they are able sell much more than they used to, they identified and separated simple manual tasks and allocated those tasks to workers, inside or outside the factory, who are not qualified to be designers or craftsmen. As such, the products remain a creative industry's product, yet the production process is increasingly manned by unskilled workers.

We also disagree with orthodox Marxist for their teleological view underpinning its deskilling thesis. For Marx (1857/1973), the emergence of large manufacturers in the early development of capitalism was historical progress, which cannot be reverted. That is why, despite their criticism related to alienation, Marx and Engels (1848/1998), in the Communist Manifesto, were highly critical of socialists such as Sismondi, who advocated a return to small workshop-based production. Similarly, for Braverman (1974), deskilling was a new phase in the history of capitalism, and a reversion to craftsmanship was not seen feasible. XCFC's case demonstrates that deskilling is highly affected by external conditions, especially the quality and quantity of demand. We saw the fast progression of deskilling in the midst of market expansion. But we also saw partial reskilling of the cluster responding to a change in consumers' taste. We can easily imagine that if the market for traditional woodcraft suddenly falls, the cluster can revert to the past. The majority of unskilled workers will leave the industry and the remaining craftsmen will undertake whole production processes covering all 
type of jobs including those that do not require skills.

The importance of market conditions was, in fact, discussed by Adam Smith in his discussion on the division of labor. Economic geographers are familiar with his explanation about the efficiency that division of labor brings. However, not enough attention was paid to the fact that he saw market expansion as the cause of further division of labor. He wrote that the division of pin-making labor into wire drawing, straightening, cutting, pointing, head-making, etc. (Smith, 1827: 3) is limited by "the extent of the market" (Smith, 1827: 8). Based on the theoretical and empirical studies above, we conclude that creative industries are more similar to manufacturing industries than the champions of creative economy made us believe. The emergence and expansion of creative industries is not necessarily the resurgence of skills. Rather than being irreversible and economy-wide, we argue that the transformation between creative and non-creative labor is reversible, industry-specific, and contingent upon the market.

\section{References}

Agnew, A., Forrester, P., Hassard, J. and Procter, S., 1997. Deskilling and reskilling within the labour process: The case of computer integrated manufacturing. International Journal of Production Economics, 52(3), pp.317-324.

Banks, M. and Milestone, K., 2011. Individualization, gender and cultural work. Gender, Work \& Organization, 18(1), pp.73-89.

Banks, M., 2010. Craft labour and creative industries. International journal of cultural policy, 16(3), pp.305-321.

Banks, M., 2007. The politics of cultural work. Basingstoke: Palgrave Macmillan.

Bell, D., 1976, May. The coming of the post-industrial society. In The Educational Forum (Vol. 40, No. 4, pp. 574-579). Taylor \& Francis Group.

Bertacchini, E. and Borrione, P., 2013. The geography of the Italian creative economy: the special role of the design and craft-based industries. Regional Studies, 47(2), pp.135-147.

Blair, H., Grey, S. and Randle, K., 2001. Working in film-Employment in a project based industry. Personnel Review, 30(2), pp.170-185.

Boggs, J., 2009. Cultural industries and the creative economy-vague but useful concepts. Geography Compass, 3(4), pp.1483-1498.

Bontje, M. and Musterd, S., 2009. Creative industries, creative class and competitiveness: Expert opinions critically appraised. Geoforum, 40(5), pp.843-852.

Braverman, H., 1974. Labor and monopoly capital: The degradation of work in the twentieth century. New York: Monthly Review Press

Amin, A. (Ed.) 1994. Post-Fordism: A Reader. Oxford: Blackwell Publishers Ltd.

Scott, A. J., \& Storper, M. (Eds.) 1992. Pathways to industrialization and regional development. Routledge. 
Brophy, E. and de Peuter, G., 2007. Immaterial labor, precarity and recomposition.

Knowledge workers in the information society, 2007, pp.177-192.

Burawoy, M., 1979. Manufacturing consent: Changes in the labor process under monopoly capitalism. University of Chicago Press.

Butler, Judith. Precarious life: The powers of mourning and violence. Verso, 2006.

Burawoy, M., Braverman, H. and Sweezy, P.M., 1996. A classic of its time.

Camfield, D., 2007. The multitude and the kangaroo: A critique of Hardt and Negri's theory of immaterial labour. Historical Materialism, 15(2), pp.21-52.

Caldwell, J.T., 2008. Production culture: Industrial reflexivity and critical practice in film and television. Duke University Press.

Chen, S., and Wen, X., 2007. 'Xianyou, Fujian - the Capital of Chinese Artisanal Furniture'. The People Daily, 23 November.

Christopherson, S. and Storper, M., 1989. The effects of flexible specialization on industrial politics and the labor market: The motion picture industry. Industrial \& Labor Relations Review, 42(3), pp.331-347.

Kiely, R. 1998. Globalization, post-Fordism and the contemporary context of development. International Sociology, 13(1), pp. 95-115.

Christopherson, S., 2008. Beyond the self-expressive creative worker an industry perspective on entertainment media. Theory, culture \& society, 25(7-8), pp.73-95.

Drotner, K., 2008. Leisure is hard work: Digital practices and future competencies. Youth, identity, and digital media, pp.167-184.

Fleming, P., Harley, B. and Sewell, G., 2004. A little knowledge is a dangerous thing: Getting below the surface of the growth of 'knowledge work'in Australia. Work, Employment \& Society, 18(4), pp.725-747.

Florida, R., 2002. The rise of the creative class: and how it's transforming work, leisure, community and everyday life. New York: Basic.

Florida, R., Mellander, C. and Stolarick, K., 2008. Inside the black box of regional development - human capital, the creative class and tolerance. Journal of economic geography, 8(5), pp.615-649.

Frenette, A., 2014. The intern economy: Laboring to learn in the music industry.

Gertler, M. 1995. "Being there": proximity, organization, and culture in the development and adoption of advanced manufacturing technologies. Economic geography. 71(1): pp. $1-26$.

Gramsci, A. and Palan, P., 1971. Americanism and fordism.

Grabher, G., 2004. Learning in projects, remembering in networks? Communality, sociality, and connectivity in project ecologies. European urban and regional studies, 11(2), pp.103-123.

Grabher, G., 2002. The project ecology of advertising: tasks, talents and teams. Regional studies, 36(3), pp.245-262.

Gibson-Graham, J.K., 1996. "The” End of Capitalism (as We Knew It): A Feminist Critique of Political Economy; with a New Introduction. U of Minnesota Press. 
Gill, R. and Pratt, A., 2008. In the social factory? Immaterial labour, precariousness and cultural work. Theory, culture \& society, 25(7-8), pp.1-30.

Giuliani, E., 2007. The selective nature of knowledge networks in clusters: evidence from the wine industry. Journal of economic geography, 7(2), pp.139-168.

Hardt, M. and Negri, A., 2005. Multitude: War and democracy in the age of empire. Penguin.

Hardt, M. and Negri, A., 2001. Empire. Harvard University Press.

Harrison, L. 1994. Lean and Mean: Why Large Corporations Will Continue to Dominate the Global Economy. Guilford Press

Harry, B., 1974. Labor and monopoly capital. New York: Monthly Review Press.

Harvey, D., 2007. A brief history of neoliberalism. Oxford University Press, USA.

Harvey, D., 1989. The condition of postmodernity (Vol. 14). Oxford: Blackwell.

Harvey, D., 1982. The limits to capital Blackwell.

Hervas-Oliver, J.L. and Albors-Garrigos, J., 2009. The role of the firm's internal and relational capabilities in clusters: when distance and embeddedness are not enough to explain innovation. Journal of Economic Geography, 9(2), pp.263-283.

Hesmondhalgh, D. and Baker, S., 2008. Creative work and emotional labour in the television industry. Theory, Culture \& Society, 25(7-8), pp.97-118.

Huws, U., 2009. The making of a cybertariat? Virtual work in a real world. Socialist register, 37(37).

Jameson, F., 1991. Postmodernism, or, the cultural logic of late capitalism. Duke University Press.

Kalleberg, A.L., 2009. Precarious work, insecure workers: Employment relations in transition. American sociological review, 74(1), pp.1-22.

Keane, M., 2009. Creative industries in China: four perspectives on social transformation. International Journal of Cultural Policy, 15(4), pp.431-443.

Keane, M. and Zhang, W., 2008. Cultural creative industries or creative (cultural) industries?. In China's Cultural Industries Forum (Chinese publication). Shanghai Peoples' Publishing.

Lazzarato, M., 1996. Immaterial labour. Radical thought in Italy: A potential politics, 1996, pp.133-47.

Lazzeretti, L., Boix, R. and Capone, F., 2008. Do creative industries cluster? Mapping creative local production systems in Italy and Spain. Industry and innovation, 15(5), pp.549-567.

Lewis, J.P., 2004. Team-based project management. Beard Books.

Lipietz, A., 1997. The post-Fordist world: labour relations, international hierarchy and global ecology. Review of International Political Economy, 4(1), pp.1-41.

Liu, D., 2014. The Impact of Xianyou Artisanal Furniture on the County's Economy, Master Thesis, Chinese Academy of Forestry.

Manning, S. and Sydow, J., 2007. Transforming creative potential in project networks: How TV movies are produced under network-based control. Critical Sociology, 33(1-2), pp.19-42. 
Markusen, A., Wassall, G.H., DeNatale, D. and Cohen, R., 2008. Defining the creative economy: Industry and occupational approaches. Economic development quarterly, 22(1), pp.24-45.

Markusen, A., 2006. Urban development and the politics of a creative class: evidence from a study of artists. Environment and planning A, 38(10), pp.1921-1940.

Markusen, Ann. 2013. Fuzzy concepts, proxy data: why indicators would not track creative placemaking success. International Journal of Urban Sciences 17.3: 291-303.

Marx, K., 1858/1993. Grundrisse. Penguin.

Marx, K., 1867/1992. Capital: Volume 1: A Critique of Political Economy. Penguin Classics

Marx, K., and Engeles, F., 1948/1998. Communist Manifesto ElecBook: London

Massey, D., 1994. Space, place and gender. John Wiley \& Sons.

McKinlay, A. and Smith, C. eds., 2009. Creative labour: Working in the creative industries. Palgrave Macmillan.

McRobbie, A., 2002. Clubs to companies: Notes on the decline of political culture in speeded up creative worlds. Cultural studies, 16(4), pp.516-531.

Meiksins, P., 1988. The" Revolt of the Engineers" reconsidered. Technology and Culture, 29(2), pp.219-246.

Menger, P.M., 1999. Artistic labor markets and careers. Annual review of sociology, pp.541-574.

Morgan, G., Wood, J. and Nelligan, P., 2013. Beyond the vocational fragments: Creative work, precarious labour and the idea of 'Flexploitation'. The economic and labour relations review, 24(3), pp.397-415.

Morrison, A., 2008. Gatekeepers of knowledge within industrial districts: who they are, how they interact. Regional Studies, 42(6), pp.817-835.

Murphy, J. and Carmody, P., 2015. Africa's information revolution: technical regimes and production networks in South Africa and Tanzania. John Wiley \& Sons.

Murphy, J., 2006. The sociospatial dynamics of creativity and production in Tanzanian industry: urban furniture manufacturers in a liberalizing economy. Environment and Planning A, 38(10), pp.1863-1882.

Neff, G., Wissinger, E. and Zukin, S., 2005. Entrepreneurial labor among cultural producers:"Cool" jobs in "hot" industries. Social semiotics, 15(3), pp.307-334.

Palmer, L., forthcoming. Lost in Translation: Journalistic Discourse on news 'fixers'. Urban Review with Journalism Studies.

Penn, R. and Scattergood, H., 1985. Deskilling or enskilling?: an empirical investigation of recent theories of the labour process. British Journal of Sociology, pp.611-630.

Perrons, D., 2003. The new economy and the work life balance. A case study of the new media sector in Brighton and Hove. Gender, Work and Organisation, 10(1), pp.65-93.

Pickles, J., Smith, A., Begg, R., Bucek, M., Roukova, P. and Rudolf, P.Ã., 2016. Articulations of capital: global production networks and regional transformations. John Wiley \& Sons.

Piore, M. and Sabel, C., 1984. The second industrial division. New York: Basic Brookes. 
Pratt, A., 1997. The cultural industries production system: a case study of employment change in Britain, 1984-91. Environment and planning A, 29(11), pp.1953-1974.

Rantisi, N., 2014. Gendering fashion, fashioning fur: on the (re) production of a gendered labor market within a craft industry in transition. Environment and Planning D: Society and Space, 32(2), pp.223-239.

Rantisi, N., Leslie, D., mimeo. The McDonald's of Circus: Corporatization, Standardization and the Erosion of Creativity at the Cirque du Soleil

Rantisi, N, 2002. The local innovation system as a source of'variety': openness and adaptability in New York City's garment district. Regional Studies, 36(6), pp.587-602.

Roberts, J., 2007. The intangibilities of form: skill and deskilling in art after the readymade. London: Verso.

Ross, A., 2009. Nice work if you can get it: Life and labor in precarious times. NYU Press.

Saxenian, A., 1994. Regional networks: industrial adaptation in Silicon Valley and route 128.

Sennett, R., 2008. The craftsman. Yale University Press.

Scott, A., 2014. Beyond the creative city: cognitive-cultural capitalism and the new urbanism. Regional Studies, 48(4), pp.565-578.

Scott, A.J., 2010. Cultural economy and the creative field of the city. Geografiska Annaler: Series B, Human Geography, 92(2), pp.115-130.

Scott, A. and Storper, M., 2007. Regions, globalization, development. Regional studies, 41(S1), pp.S191-S205.

Scott, A., 2000. The cultural economy of cities: essays on the geography of image-producing industries. Sage.

Scott, A., 1997. The cultural economy of cities. International journal of urban and regional research, 21(2), pp.323-339.

Sonn, J., and Lee, D., 2015. Heterogeneity as the source of the state's resilience: the case of spatial planning under state-led neoliberalization in South Korea. International Journal of Urban Sciences 19(3) pp. 364-378.

Steiger, T and Wardell, M., 1992. The labor reserve and the skill debate. The Sociological Quarterly, 33(3), pp.413-433.

Sparke, M., 2005. In the space of theory: Postfoundational geographies of the nation-state (Vol. 26). U of Minnesota Press.

Storper, M. and Walker, R., 1983. The theory of labour and the theory of location. International Journal of Urban and Regional Research, 7(1), pp.1-43.

Xinhua News 2015`Taihe Garden and the Revolutionary Force in Chinese Wood Crafts, Silk Carving', 28 April . Available from: http://www.gs.xinhuanet.com/news/2015-04/28/c_1115117236.htm. [15 February 2017].

Terranova, T., 2000. Free labor: Producing culture for the digital economy. Social text, 18(2), pp.33-58.

Thompson, E, 1963. The making of the British working class. New York: Pantheon.

Thompson, P., Warhurst, C. and Callaghan, G., 2001. Ignorant theory and knowledgeable 
workers: Interrogating the connections between knowledge, skills and services. Journal of Management Studies, 38(7), pp.923-942.

Tian, Y., 2011. 'Shenzhen Brush Pot with Silk Carving Techniques Included in the Palace Museum Collection', Tencent News. 02 August. Available from: http://finance.qq.com/a/20110802/005841.htm. [15 February 2017].

Ursell, G., 2003. Creating Value and Valuing Creation in Contemporary UK Television: or" dumbing down" the workforce. Journalism Studies, 4(1), pp.31-46.

Wang, J. and Li, S.M., 2016. State territorialization, neoliberal governmentality: the remaking of Dafen oil painting village, Shenzhen, China. Urban Geography, pp.1-21.

Watson, A. and Beaverstock, J., 2016. Transnational freelancing: Ephemeral creative projects and mobility in the music recording industry. Environment and Planning A, online.

White, H.C. and White, C.A., 1965. Canvases and careers: Institutional change in the French painting world. University of Chicago Press.

Wingfield, I., Crompton, R. and Jones, G., 1985. White-Collar Proletariat: Deskilling and Gender in Clerical Work.

Wreyford, N., 2015. Birds of a feather: Informal recruitment practices and gendered outcomes for screenwriting work in the UK film industry. The Sociological Review, 63(S1), pp.84-96.

Wood, S., 1987. The deskilling debate, new technology and work organization. Acta sociologica, 30(1), pp.3-24.

Xianyou Bureau of Arts and Crafts, 2015. 2014 Annual Report on Xianyou Artisanal Furniture Industry.

Zicklin, G., 1987. Numerical Control Machining and the Issue of Deskilling An Empirical View. Work and Occupations, 14(3), pp.452-466.

Zhu, H., Chen, K. W., and Dai, J. 2016. Beyond Apprenticeship: Knowledge Brokers and Sustainability of Apprentice-Based Clusters. Sustainability 8(12), pp.1279.

Zukin, S., 1995. Whose culture? Whose city?. The urban sociology reader, pp.281-289. 